\title{
ANALISIS PENYEBAB KETIDAKSESUAIAN PRODUKSI FLUTE PADA RUANG HANDATSUKE DENGAN PENDEKATAN FISHBONE DIAGRAM, PIRAMIDA KUALITAS DAN FMEA
}

\author{
Akhmad Ghiffary Budianto \\ Teknik Industri, Fakultas Teknik, Universitas Islam Kalimantan Muhammad Arsyad Al-Banjari \\ Jl. Adhyaksa, Jl. Kayu Tangi 1 Jalur 2 No.2, Sungai Miai, Kec. Banjarmasin Utara, Kota Banjarmasin, \\ Kalimantan Selatan 70123 \\ Email : ghiffaryb04@gmail.com
}

\begin{abstract}
Abstrak-Tujuan penelitian adalah untuk memberikan gambaran upaya pencapaian zero defect pada proses produksi flute dan memberikan rekomendasi tindakan bagi pihak terkait dalam proses produksi flute berdasarkan penilaian RPN tertinggi-terendah. Metode penelitian yang digunakan adalah analisis dengan ishikawa chart/fishbone diagram, PokaYoke (Piramida Kualitas) dan FMEA. Penelitian ini adalah studi kasus di ruang handatsuke pada proses produksi flute. Hasil penelitian menunjukan bahwa dengan hasil FMEA dapat memberikan manajemen risiko kualitas produksi yang lebih baik. Hal ini terbukti dari defect yang paling sering terjadi adalah Handa Tare sebanyak 471 kali dalam 3 bulan dengan nilai RPN 210 yang disebabkan oleh proses soldering kawat nikel yang melebar pada permukaan item. Rekomendasi tindakan yang disarankan yaitu pemberian informasi sebabakibat dan teknik soldering yang sesuai dengan kaidah tangan kanan-kiri. Rekomendasi tersebut ditujukan kepada pekerja dan KK (Ketua Kelompok) pada ruang handatsuke.
\end{abstract}

Kata Kunci : Manajemen Risiko, FMEA, Piramida Kualitas, Fishbone Diagram

\section{PENDAHULUAN}

$\mathrm{P}$ erusahaan manufaktur jepang pada umumnya menerapkan Sistem Produksi Tepat Waktu (Just in Time). Just in Time (JIT) merupakan konsep untuk mengurangi ongkos produksi dan meningkatkan produktivitas sebuah manufaktur dengan cara berusaha menghilangkan pemborosan (waste) yang awalnya diterapkan oleh Toyota Manufaktur [1].

PT. XYZ yang menggunakan sistem produksi tepat waktu (Just In Time) atau yang juga dikenal dengan Toyota Production System. Penggunaan Just In Time menggunakan dasar produksi tepat waktu, tepat kuantitas, tepat kualitas. Perusahaan sangat memperhatikan kualitas dari alat musik yang diproduksi, oleh karena itu perusahaan ini menggunakan 2 metode untuk memperhatikan kualitas yaitu secara fisik dan waktu pengerjaan dari sebuah produk. Maksud kualitas secara fisik yaitu setiap selesai proses, produk akan langsung di cek kualitas fisiknya oleh operator kensa apakah dikatakan OK atau NG (Not Good). Klasifikasi produk yang dikatakan NG yaitu terdapat nami dan kizu. Nami yaitu adanya gelombang ke bagian dalam dari fisik produk sedangkan kizu yaitu pada fisik produk terdapat baret halus akibat proses produksi yang terlalu berlebih. Kizu bisa muncul dari produk yang dikerjakan berulang-ulang kali. Jika pada fisik produk terdapat nami maupun kizu maka produk tersebut harus dikerjakan ulang sampai dikatakan OK. Kualitas secara waktu yaitu produk yang dikatakan OK dikerjakan dengan waktu yang telah ditetapkan standart waktu pengerjaannya, karena apabila produk tersebut dikerjakan melebihi dari waktu yang telah distandarkan oleh perusahaan maka dari situ perusahaan bisa mengindikasikan adanya kecacatan pada produk. Hal ini juga mengganggu rencana produksi yang telah ditetapkan karena bagian perencanaan produksi tidak memasukkan waktu untuk mengerjakan ulang produk yang dikatakan NG tersebut sebagai waktu untuk memproduksi sebuah produk.

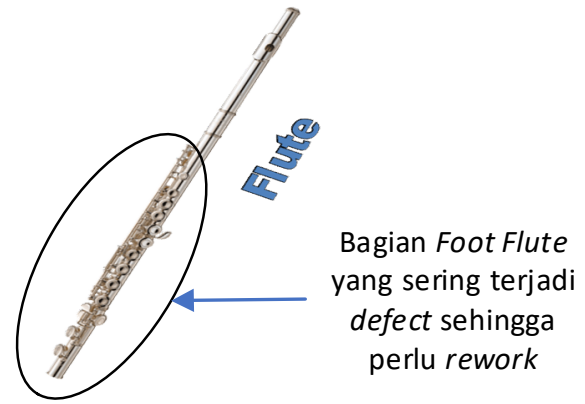

Gambar 1. Foot Flute yang sering di rework

Permasalahan yang umum dihadapi oleh manufaktur dalam proses produksi flute yaitu sering terjadi 4 jenis cacat pada bagian foot flute di ruang Handatsuke. Keempat jenis cacat ini terus terjadi secara berulang pada proses produksi flute. Hal ini tentu menambah waktu pengerjaan ulang (rework) dan inspeksi dari item defect tersebut. Sesuai dengan penjelasan sebelumnya, hal ini tentu mengganggu rencana produksi yang telah ditetapkan sebelumnya.

Dalam mengatasi permasalahan diatas, perusahaan manufaktur sudah menerapkan sistem kaizen, PDCA (PlanDo-Check-Action) dan Piramida Kualitas untuk mencapai zero complain. Dalam penelitian ini, konsep Failure Mode Effect Analysis (FMEA) diajukan sebagai acuan lain untuk manajemen risiko kualitas dari cacat produksi yang sering terjadi. FMEA adalah teknik yang digunakan untuk mencari, mengidentifikasi, dan menghilangkan potensi kegagalan, kesalahan, dan masalah yang diketahui dari sistem, desain, proses, atau jasa sebelum terserah kepada pelanggan. Proses FMEA di sini adalah untuk mendeteksi risiko yang teridentifikasi selama proses tersebut. Pada beberapa penelitian terdahulu terkait industri manufaktur memiliki kesamaan dimana konsep kaizen dan PDCA dapat digabungkan dengan metode FMEA untuk mencapai zero complain.

Pada penelitian terdahulu, secara dasar FMEA dapat digunakan sebagai alat manajemen risiko kualitas dari proses produksi manufaktur. Penggunaan FMEA sebagai alat untuk dapat meningkatkan kualitas dan keandalan secara keseluruhan baik produk maupun proses. Faktor biaya kualitas digunakan untuk menghitung biaya kegagalan internal akibat efek dari kegagalan suatu proses [2]. Sebagai tambahan Poka-Yoke (Piramida Kualitas) cocok dengan proses FMEA dimana FMEA melakukan pengurangan 
penyebab cacat yang terkait langsung dengan terjadinya kesalahan penyebab cacat produksi. Lalu Poka-Yoke berfokus pada sistem deteksi, kontrol dan tindakan akan diambil oleh manajemen terkait. Integrasi kedua konsep ini dapat memfasilitasi peningkatan proses dan kapabilitas manufaktur [3]. Sebagai pendekatan manajemen risiko yang berdiri sendiri, FMEA digunakan untuk menganalisis moda kegagalan dan mendapatkan risiko kegagalan proses produksi terbesar. Dari kedua hal ini maka didapatkan informasi yang berguna bagi manufaktur dalam melakukan perbaikan kualitas dalam proses produksinya [4]. Terkait dengan usaha dalam zero defect/complain, penerapan six sigma dan FMEA bisa dikombinasikan. Hasil dari kombinasi tersebut dapat memberikan potensi pengurangan tingkat cacat dan pencapaian kualitas yang baik dalam hal usaha zero defect [5]. Untuk faktor subjektivitas penilaian pada pendekatan FMEA dapat dikurangi dengan menggunakan konsep Fuzzy. Konsep Fuzzy ditambahkan sebagai aspek penilaian yang samar terhadap severity, occurance dan defect dari mesin. Hasil Fuzzy FMEA lebih direkomendasikan daripada FMEA konvensional karena lebih objektif dalam penilaian untuk perbaikan dan perawatan mesin [6]. lain:

Tujuan yang hendak dicapai melalui penelitian ini antara

1. Memberikan gambaran upaya pencapaian zero defect pada proses produksi flute

2. Memberikan rekomendasi tindakan bagi pihak terkait dalam proses produksi flute berdasarkan penilaian RPN tertinggi-terendah

Pertanyaan-pertanyaan yang dikembangkan dan hendak ditemukan jawabannya melalui penelitian ini adalah:

1. Bagaimana gambaran upaya pencapaian zero defect pada proses produksi flute

2. Apa rekomendasi tindakan berdasarkan hasil FMEA dan ditujukan ke pihak terkait yang mana rekomendasi tindakan tersebut dalam proses produksi flute

Usaha manufaktur dalam mencapai zero defect dalam proses produksi flute sangat mungkin untuk tercapai jika menerapkan beberapa tools pengendalian kualitas secara bersamaan diantaranya fishbone diagram sebagai analisis untuk $5 \mathrm{~m}$ dan $1 \mathrm{e}$, piramida kualitas untuk gambaran dari pencapaian zero defect dari bagian paling bawah-paling atas dan FMEA untuk manajemen risiko dari kegagalan yang sering terjadi pada proses produksi flute.

Berdasarkan penelusuran dokumen, dokumen laporan penelitian dan referensi tertulis lainnya dilingkungan perusahaan manufaktur. Penelitian ini bersifat original dan tidak terduplikasi dengan data dokumen maupun hasil penelitian yang ada dilingkungan perusahaan manufaktur PT. XYZ.

\section{METODE PENELITIAN}

\section{Tinjauan Pustaka}

a. Ishikawa Chart/Fishbone Diagram

Ishikawa Chart/Fishbone Diagram merupakan salah satu tools populer yang menggambarkan identifikasi dari penyebab suatu masalah pada suatu proses dari sisi man, machine, method, material, measurement, dan environment/equipment. Diagram ini dikembangkan pada tahun 1950 oleh Professor Kaoru Ishikawa [7]. Diagram ini juga sering disebut dengan Cause-and-Effect Diagram. Diagram ini pertama kali diaplikasikan pada masalah manufaktur. Namun seiring waktu penerapan diagram ini berkembang ke arah masalah yang lebih universal.

b. Piramida Kualitas (Poka-Yoke)

Piramida kualitas yaitu pembagian kerja yang ditetapkan pada bidang tanggung jawab untuk mengendalikan kualitas sehingga mewujudkan zero complain. Kontrol yang dimaksud dimaksud yaitu dengan man, method, machine dan material [7]. Berikut piramida kualitas yang digunakan perusahaan dalam mewujudkan zero complain. Pada piramida kualitas juga disebukan sistem poka-yoke. Sistem poka-yoke juga diterapkan pada perusahaan sebagai langkah pencegahan defect yang diakibatkan 4M (machine, man, method and material). Prinsip poka-yoke adalah mencegah terjadinya kesalahan baik itu akibat kesalahan manusiawi, mesin, maupun metode yang digunakan.

c. Failure Mode and Effect Analysis (FMEA)

FMEA adalah teknik yang digunakan untuk mencari, mengidentifikasi, dan menghilangkan potensi kegagalan, kesalahan, dan masalah yang diketahui dari sistem, desain, proses, atau jasa sebelum terserah kepada pelanggan. FMEA Proses FMEA di sini adalah untuk mendeteksi risiko yang teridentifikasi selama proses tersebut [8].Setiap komponen komponen seperti memiliki komponen - masing-masing, yang bekerja secara individu, bersama-sama, atau bahkan merupakan suatu interaksi untuk menghasilkan kegagalan.

Severity adalah penilaian dari keseriusan efek. Dalam setiap arti kegagalan yang timbul akan dinilai seberapa besar tingkat keseriusan. Ada hubungan langsung antara efek dan tingkat keparahan. Sebagai contoh, jika efek terjadi adalah efek kritis, maka nilai akan keparahan tinggi. Kejadian kemungkinan penyebab akan terjadi dan menghasilkan bentuk kegagalan selama penggunaan produk. Nilai rating Kejadian yang disesuaikan dengan frekuensi yang diharapkan dan atau jumlah kumulatif kegagalan yang dapat terjadi. Nilai Deteksi berhubungan dengan kontrol saat ini. Deteksi adalah pengukuran kemampuan untuk mengendalikan kegagalan/control yang mungkin terjadi. Risiko Nilai Rank Priority Number ( RPN ) adalah produk dari perkalian dari keparahan, tingkat kejadian, dan tingkat deteksi. RPN tidak memiliki nilai atau makna. Nilai ini digunakan untuk menentukan peringkat kegagalan proses potensial [9]. Nilai RPN dapat ditunjukkan dengan persamaan berikut:

$\mathrm{RPN}=$ Severity $\mathrm{x}$ Kejadian $\mathrm{x}$ Detection

(1)

Tahapan dari metode FMEA [8] antara lain:

1) Identifikasi sistem dan elemen sistem.

2) Mengidentifikasi kegagalan dan efeknya. Failure adalah keadaan dimana suatu sistem tidak berjalan sesuai dengan yang diharapkan. Effect of Failure merupakan konsekuensi yang ditimbulkan oleh suatu kegagalan.

3) Menentukan tingkat keparahan efek dari suatu kegagalan (severity). Tim FMEA dapat menentukan kriteria severity sendiri atau menggunakan kriteria

4) Menentukan Occurrence. Occurrence menyatakan frekuensi atau jumlah kegagalan yang terjadi karena suatu penyebab. Tingkat occurrence dimulai dari angka 
1 (tingkat kejadian rendah) hingga 10 (tingkat kejadian sering).

5) Menentukan Tingkat Deteksi (Detection). Tingkat deteksi menyatakan tingkat ketelitian suatu metode deteksi untuk mendeteksi kegagalan. Tingkat deteksi mulai dari angka 1 hingga 10. Semakin kecil tingkat deteksi, maka semakin tinggi kemampuan metode deteksi untuk mendeteksi kegagalan.

6) Menghitung Risk Priority Number (RPN). RPN menyatakan tingkat resiko dari suatu kegagalan. Angka RPN berkisar antara $1-1000$, semakin tinggi angka RPN maka semakin tinggi resiko suatu potensi kegagalan terhadap sistem, desain, proses maupun pelayanan. Perhitungan RPN dengan persamaan (1).

7) Memberikan rekomendasi tindakan untuk mengurangi tingkat resiko kegagalan

d. Jenis Defect pada Proses Produksi Flute Adapun permasalahan mengenai NG yang terjadi pada proses produksi flute yaitu seringnya terjadi empat jenis cacat produksi antara lain:

1. Handa Oi yaitu cacat pada produk yang dikarenakan proses penyolderan kawat timah pada flute terlalu banyak dan bulu kuas untuk pengolesan cairan flux sudah melebar akibat terlalu sering digunakan dan efek terkena panas solder lalu dicelupkan ke dalam air.

2. Kizu Kenchu yaitu cacat pada flute bagian kenchu seperti tergores atau tergesek. Hal ini diakibatkan oleh sisa serbuk (bari) yang masih terdapat pada permukaan flute yang akan dilakukan proses drilling.

3. Handa Tare yaitu cacat pada permukaan flute yang diakibatkan penyolderan kawat timah yang terlalu panas sehingga menyebabkan cairan timah melebar

4. Handa Zara yaitu cacat pada permukaan flute yang diakibatkan proses penyolderan yang tidak sempurna sehingga menimbulkan bintik-bintik pada permukaan flute.

\section{Metode Penelitian}

Penelitian ini dilakukan dilingkungan industri Manufaktur PT. XYZ yang memproduksi alat musik flute. Metode penelitian yang digunakan adalah analisis dengan ishikawa chart/fishbone diagram untuk penyebab defect pada flute dari man/personnel, machine, method, material dan environment $(4 \mathrm{~m}+1 \mathrm{e})$. Dilanjutkan dengan penggunaan metode Poka-Yoke (Piramida Kualitas) untuk memberikan gambaran pencapaian zero defect pada proses produksi paling bawah-atas. Setelah mengetahui faktor defect dan gambaran pencapaian zero defect, maka dilakukan pengukuran jumlah defect yang paling sering terjadi dengan pendekatan pareto chart. Setelah mengetahui jenis cacat yang paling sering terjadi pada proses produksi flute, maka dapat dilakukan analisis dengan metode FMEA. Hasil dari FMEA berupa rekomendasi tindakan dan kepada siapa tindakan tersebut ditujukan. Hal ini dapat memperkuat piramida kualitas dalam pencapaian zero defect sebagai manajemen risiko kualitas proses produksi. Untuk lebih jelasnya dapat dilihat pada diagram alir penelitian sebagai berikut:
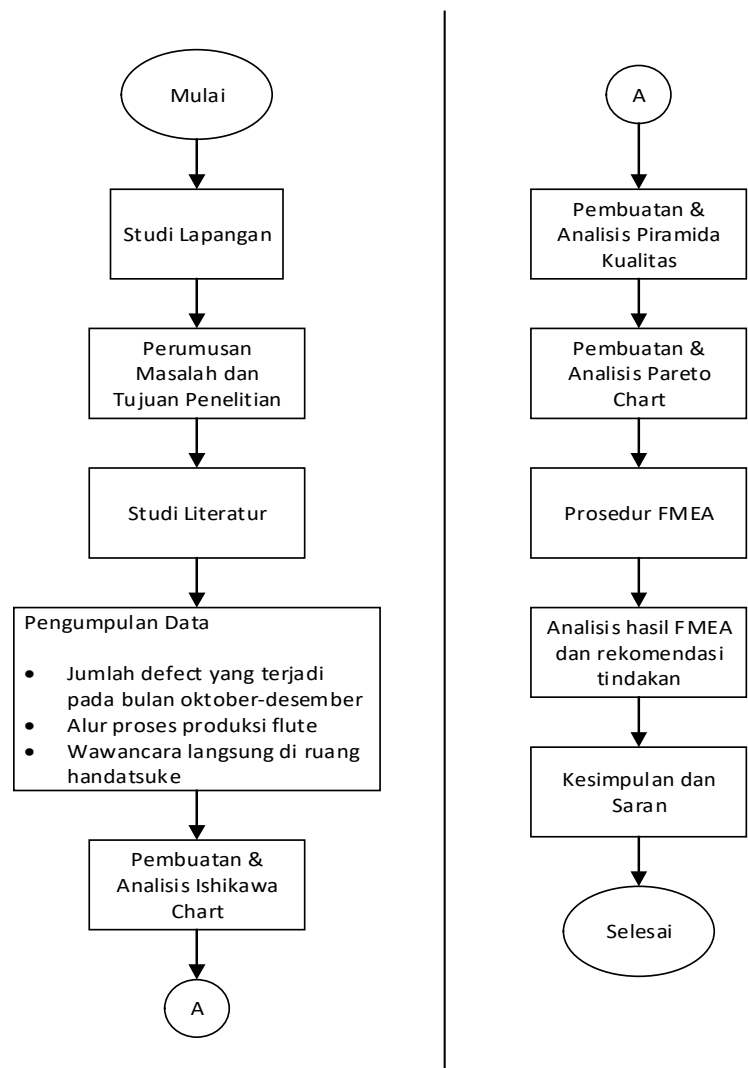

Gambar 2. Diagram Alir Penelitian

\section{Metode Pendekatan}

Metode pendekatan yang digunakan pada penelitian ini pendekatan studi kasus dan data pengendalian kualitas dari dokumen proses produksi manufaktur. Studi kasus berupa pengukuran langsung dengan batasan masalah yang ada pada proses produksi flute. Sedangkan data dari dokumen pengendalian kualitas bertujuan untuk memperkuat pengukuran langsung yang dilakukan. Data yang dikumpulkan yaitu jumlah defect yang terjadi pada bulan oktober-desember, alur proses produksi flute, dan wawancara langsung terkait defect yang terjadi pada produksi flute.

\section{HASIL DAN PEMBAHASAN}

Perusahaan dalam memperhatikan kualitas produk alat musik yang diproduksi menggunakan diagram ishikawa dan piramida kualitas. Diagram ishikawa yang digunakan untuk analisis penyebab muncul defect berupa nami dan kizu pada flute di PT. XYZ sebagai berikut : 


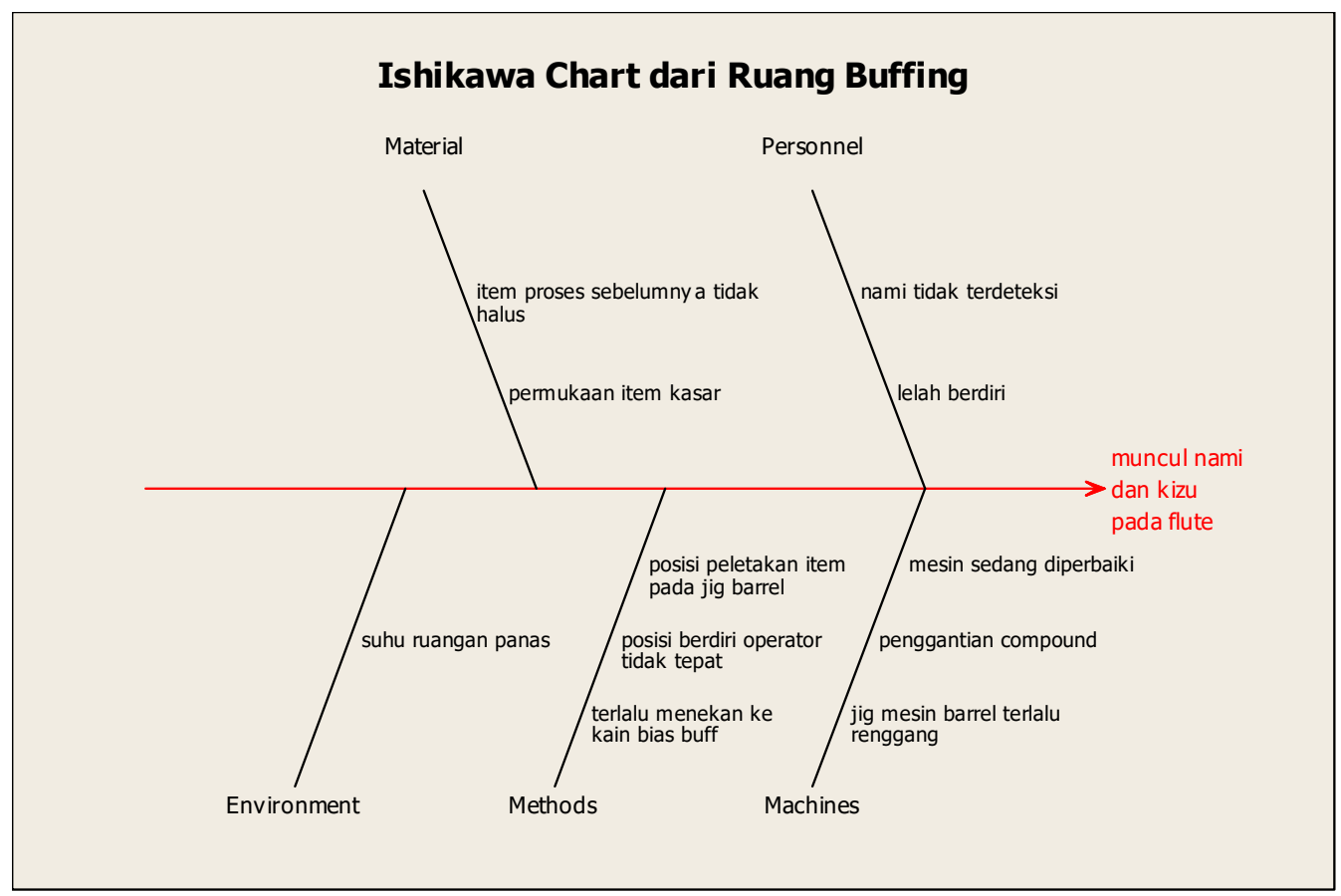

Gambar 3. Ishikawa Chart dari Ruang Buffing

Sedangkan piramida kualitas yang disusun berdasarkan guna mencapai zero defect/complain dari bagian paling hasil analisis man and method serta machine and material dasar-atas dapat dilihat pada gambar berikut:

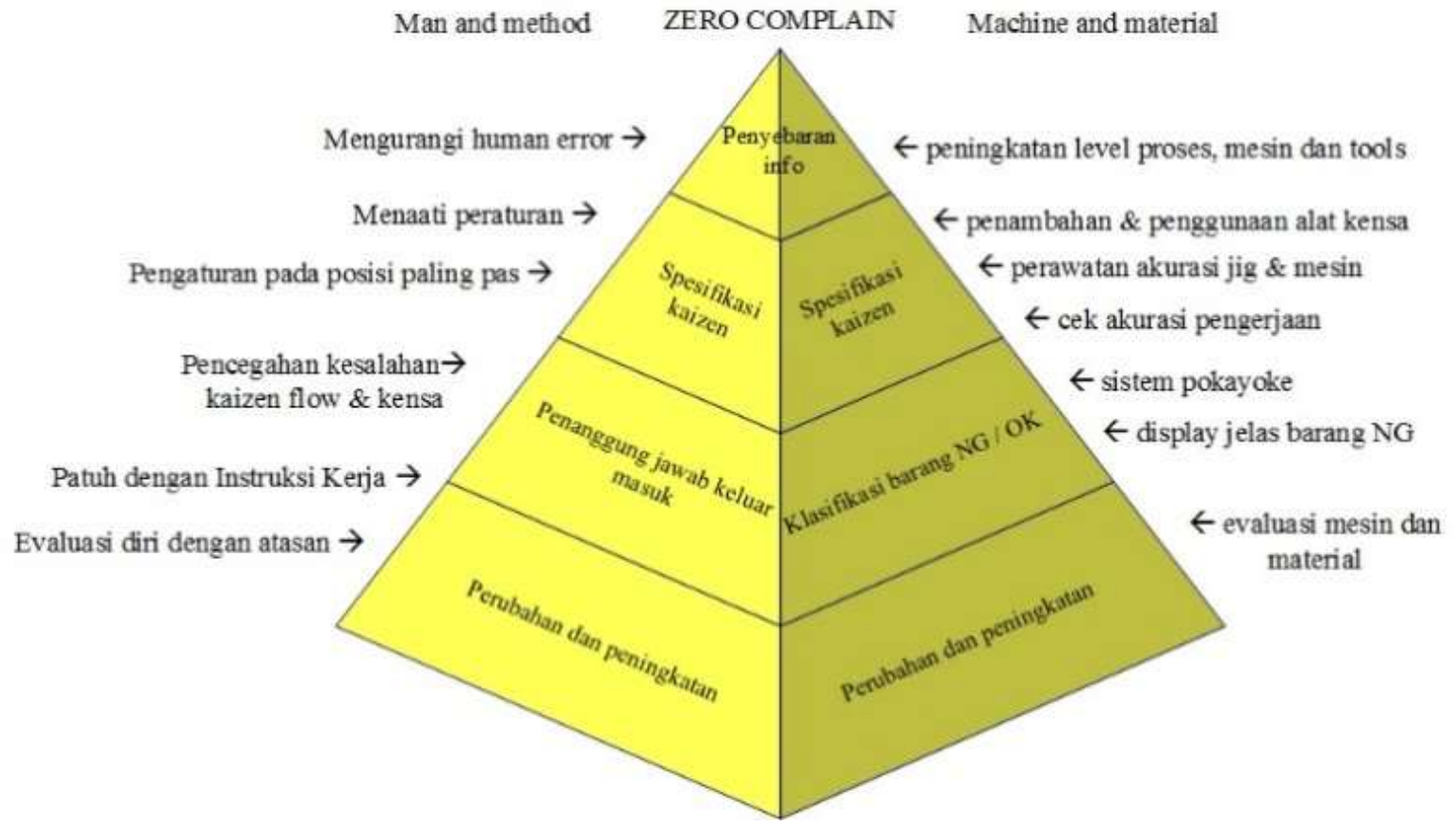

Gambar 4. Piramida Kualitas untuk mewujudkan zero defect/complain

Dari data yang telah dikumpulkan dari ruang Handatsuke, maka persentase NG dapat diolah dengan menggunakan software minitab untuk pengolahan data menjadi Pareto chart. Pareto chart digunakan untuk menganalisis jenis NG apa yang paling banyak terjadi dan berpengaruh pada proses produksi. 


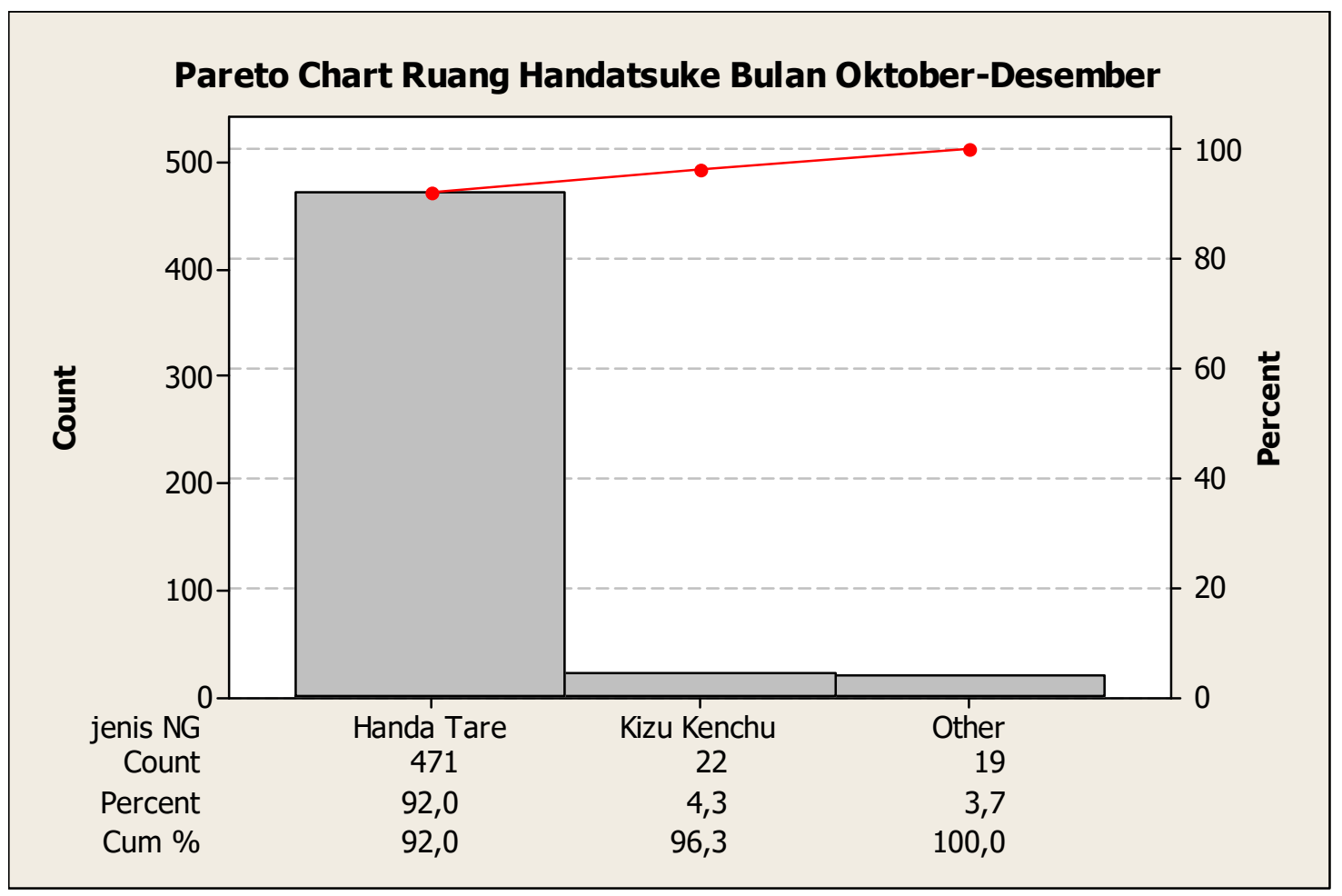

Gambar 5. Pareto Chart dari Ruang Handatsuke Bulan Oktober - Desember

Dari pareto chart diatas terlihat bahwa jenis NG yang paling banyak dalam 3 bulan yaitu Handa Tare sebanyak 471 (92\%), Kizu Kenchu sebanyak 22 (4.3\%) dan yang lainnya ( handa zara \& Handa Oi) sebanyak 19 (3.7\%). Dari konsep 80:20 yang paling mempengaruhi proses produksi adalah NG jenis Handa Tare.
Setelah mengetahui bahwa NG yang paling sering terjadi adalah Handa Tare pada ruang Handatsuke. Maka selanjutnya dapat dilakukan pendekatan FMEA untuk manajemen risiko dari kualitas proses produksi flute serta sebagai upaya peningkatan kualitas manufaktur. Hasil dari FMEA dapat dilihat pada tabel 1 dan 2 sebagai berikut:

Tabel 1. Perhitungan RPN dari FMEA pada Ruang Handatsuke

\begin{tabular}{|c|c|c|c|c|c|c|c|c|}
\hline $\begin{array}{l}\text { Component } \\
\text { and Function }\end{array}$ & $\begin{array}{c}\text { Potential Failure } \\
\text { Mode }\end{array}$ & $\begin{array}{l}\text { Potential Effect } \\
\text { (s) of Failure }\end{array}$ & (S) & $\begin{array}{c}\text { Potential } \\
\text { Cause(s) of } \\
\text { Failure }\end{array}$ & (O) & $\begin{array}{c}\text { Current } \\
\text { Controls, } \\
\text { Prevention }\end{array}$ & (D) & $R P N$ \\
\hline kencususei & $\begin{array}{l}\text { tidak dapat } \\
\text { melakukan proses } \\
\text { drilling }\end{array}$ & $\begin{array}{l}\text { permukaan item } \\
\text { akan mengalami } \\
\text { NG jenis Kizu } \\
\text { Kenchu }\end{array}$ & 5 & $\begin{array}{l}\text { terdapat debu sisa } \\
\text { proses kencususei } \\
\text { pada permukaan } \\
\text { item }\end{array}$ & 4 & $\begin{array}{l}\text { operator } \\
\text { melakukan kensa } \\
\text { (inspeksi) setelah } \\
\text { selesai proses }\end{array}$ & 5 & 100 \\
\hline \multirow[b]{2}{*}{ soldering } & $\begin{array}{l}\text { kawat nikel } \\
\text { melebar di } \\
\text { permukaan item }\end{array}$ & $\begin{array}{l}\text { permukaan item } \\
\text { berpotensi NG } \\
\text { jenis Handa Tare }\end{array}$ & 7 & $\begin{array}{l}\text { keseimbangan } \\
\text { penggunaan } \\
\text { tangan kanan dan } \\
\text { kiri }\end{array}$ & 5 & $\begin{array}{l}\text { staff melakukan } \\
\text { control process } \\
\text { chart proses } \\
\text { soldering }\end{array}$ & 6 & 210 \\
\hline & $\begin{array}{l}\text { cairan flux yang } \\
\text { dioleskan melebar } \\
\text { di permukaan } \\
\text { item }\end{array}$ & $\begin{array}{l}\text { permukaan item } \\
\text { berpotensi NG } \\
\text { jenis Handa } \mathrm{Oi}\end{array}$ & 5 & $\begin{array}{l}\text { keseimbangan } \\
\text { waktu pada } \\
\text { penggunaan } \\
\text { tangan kanan dan } \\
\text { kiri }\end{array}$ & 3 & $\begin{array}{l}\text { operator } \\
\text { melakukan kensa } \\
\text { setelah selesai } \\
\text { proses }\end{array}$ & 5 & 75 \\
\hline \multirow[t]{2}{*}{ washing } & $\begin{array}{l}\text { larutan kimia } \\
\text { kurang sehingga } \\
\text { pencucian tidak } \\
\text { maksimal }\end{array}$ & $\begin{array}{l}\text { - item akan } \\
\text { dicuci berulang } \\
\text { kali } \\
\text { - item tidak } \\
\text { terendam secara } \\
\text { keseluruhan } \\
\end{array}$ & 4 & $\begin{array}{l}\text { tidak ada standart } \\
\text { batas bawah } \\
\text { larutan kimia pada } \\
\text { bak }\end{array}$ & 5 & $\begin{array}{l}\text { staff mengecek } \\
\text { rutin per bulan } \\
\text { secara visual }\end{array}$ & 8 & 160 \\
\hline & $\begin{array}{l}\text { item tidak bisa } \\
\text { lanjut di proses } \\
\text { berikutnya }\end{array}$ & $\begin{array}{l}\text { item belum bersih } \\
\text { dari sisa proses }\end{array}$ & 4 & $\begin{array}{l}\text { larutan kimia } \\
\text { sudah jenuh }\end{array}$ & 4 & $\begin{array}{l}\text { staff mengecek } \\
\text { rutin per bulan } \\
\text { secara visual }\end{array}$ & 8 & 128 \\
\hline
\end{tabular}


Tabel 2. Tingkat Prioritas dan Rekomendasi Tindakan serta Targetnya

\begin{tabular}{|c|c|c|c|c|c|c|}
\hline $\begin{array}{c}\text { Potential } \\
\text { Failure Mode }\end{array}$ & $\begin{array}{c}\text { Potential Effect (s) } \\
\text { of Failure }\end{array}$ & RPN & Rank & $\begin{array}{c}\text { Recommended } \\
\text { Actions }\end{array}$ & $\begin{array}{c}\text { Responsibility } \\
\text { and Target } \\
\text { Completion } \\
\text { Date }\end{array}$ & Action Taken \\
\hline $\begin{array}{l}\text { tidak dapat } \\
\text { melakukan } \\
\text { proses drilling }\end{array}$ & $\begin{array}{l}\text { permukaan item } \\
\text { akan mengalami } \\
\text { NG jenis Kizu } \\
\text { Kenchu }\end{array}$ & 100 & 4 & $\begin{array}{l}\text { mengecek item } \\
\text { setelah selesai proses }\end{array}$ & $\begin{array}{l}\text { KK (ketua } \\
\text { Kelompok) } \\
\text { Handatsuke }\end{array}$ & $\begin{array}{l}\text { operator meningkatkan } \\
\text { inspeksi dan } \\
\text { pengawasan terhadap } \\
\text { item }\end{array}$ \\
\hline $\begin{array}{l}\text { kawat nikel } \\
\text { melebar di } \\
\text { permukaan item }\end{array}$ & $\begin{array}{l}\text { permukaan item } \\
\text { berpotensi NG jenis } \\
\text { Handa Tare }\end{array}$ & 210 & 1 & $\begin{array}{l}\text { operator diberikan } \\
\text { informasi mengenai } \\
\text { teknik solder dengan } \\
\text { peta tangan kanan dan } \\
\text { kiri }\end{array}$ & $\begin{array}{l}\text { KK (ketua } \\
\text { Kelompok) } \\
\text { Handatsuke }\end{array}$ & $\begin{array}{l}\text { KK memberikan } \\
\text { retraining mengenai } \\
\text { teknik dengan peta } \\
\text { tangan kanan dan kiri } \\
\text { proses soldering }\end{array}$ \\
\hline $\begin{array}{l}\text { cairan flux yang } \\
\text { dioleskan } \\
\text { melebar di } \\
\text { permukaan item }\end{array}$ & $\begin{array}{l}\text { permukaan item } \\
\text { berpotensi NG jenis } \\
\text { Handa } \mathrm{Oi}\end{array}$ & 75 & 5 & $\begin{array}{l}\text { operator diberikan } \\
\text { keseimbangan peta } \\
\text { kerja tangan kanan } \\
\text { dan kiri }\end{array}$ & $\begin{array}{l}\text { KK (ketua } \\
\text { Kelompok) } \\
\text { Handatsuke }\end{array}$ & $\begin{array}{l}\text { KK memberikan } \\
\text { retraining tentang } \\
\text { keseimbangan } \\
\text { penggunaan tangan } \\
\text { kanan dan kiri }\end{array}$ \\
\hline $\begin{array}{l}\text { larutan kimia } \\
\text { kurang sehingga } \\
\text { pencucian tidak } \\
\text { maksimal }\end{array}$ & $\begin{array}{l}\text { - item akan dicuci } \\
\text { berulang kali } \\
\text { - item tidak } \\
\text { terendam secara } \\
\text { keseluruhan } \\
\end{array}$ & 160 & 2 & $\begin{array}{l}\text { melakukan } \\
\text { pengukuran tingkat } \\
\text { konsentrasi larutan } \\
\text { dan pemeliharaan } \\
\text { rutin yang terjadwal }\end{array}$ & $\begin{array}{l}\mathrm{KK} \\
\text { handatsuke }\end{array}$ & $\begin{array}{l}\text { merevisi ulang standart } \\
\text { penggunaan larutan } \\
\text { kimia }\end{array}$ \\
\hline $\begin{array}{l}\text { item tidak bisa } \\
\text { lanjut di proses } \\
\text { berikutnya }\end{array}$ & $\begin{array}{l}\text { item belum bersih } \\
\text { dari sisa proses }\end{array}$ & 128 & 3 & $\begin{array}{l}\text { melakukan } \\
\text { pengukuran tingkat } \\
\text { kejenuhan dan } \\
\text { pemeliharaan rutin }\end{array}$ & $\begin{array}{l}\mathrm{KK} \\
\text { handatsuke }\end{array}$ & $\begin{array}{l}\text { merevisi ulang standart } \\
\text { penggantian larutan } \\
\text { kimia }\end{array}$ \\
\hline
\end{tabular}

Untuk ruang produksi Handatsuke, dapat dilihat tabel 1 dan 2 nilai RPN 210 terbesar yaitu teknik dasar solder. Teknik dasar solder berpengaruh pada item yang dikerjakan. Pada penyolderan kawat timah (lit free) yang terlalu lama dipanaskan maka kawat tersebut akan melebar ketika menyentuh permukaan item. Hal ini tentu akan berpotensi menimbulkan NG jenis Handa Oi dan Handa Tare. Hal ini terbukti dengan banyaknya terjadi NG jenis Handa Tare yaitu sebanyak 471 dalam 3 bulan. Yang kedua nilai RPN 160 adalah batas bawah dari larutan kimia yang digunakan untuk pencucian. Hal ini mempengaruhi item yang akan dicuci untuk menghilangkan sisa proses sebelumnya menjadi tidak efektif karena larutan kimia berkurang. Yang ketiga nilai RPN 128 adalah larutan kimia yang sudah jenuh. Berkaitan dengan proses pencucian yang sering dilakukan tetapi tidak memiliki standar pasti kapan larutan kimia harus diganti atau ditambahkan. Hal ini berakibat pada proses pencucian ulang pada item yang tidak maksimal proses pencucian larutan kimianya.

Berdasarkan hasil FMEA ruang Handatsuke, ada beberapa rekomendasi yang bisa dilakukan adalah diantaranya:

- Pemberian informasi tentang sebab akibat dari aktivitas dan teknik soldering sesuai dengan peta kerja tangan kanan \& kiri pada operator soldering di ruang Handatsuke.

- Penetapan standart batas bawah dari bak larutan kimia dan penggantian larutan kimia yang hampir jenuh secara rutin tepat waktu

- Melakukan proses pembersihan dengan kuas untuk permukaan item dari debu sisa proses drilling agar tidak menimbulkan bari, selanjutnya dilakukan proses pencucian dengan larutan kimia.

\section{KESIMPULAN DAN SARAN}

\section{Kesimpulan}

Dari hasil-hasil penelitian dan pembahasan dapat disimpulkan hal-hal sebagai berikut :

1. Upaya manufaktur dalam pengendalian kualitas proses produksi flute sudah menerapkan beberapa konsep diantaranya konsep kaizen, JIT, siklus PDCA dan Ishikawa Chart. Namun dalam manajemen risiko kualitas masih belum menerapkan FMEA sehingga belum memiliki prioritas proses apa yang sebaiknya diperbaiki terlebih dahulu.

2. Berdasarkan hasil analisa FMEA untuk ruang Handatsuke, maka untuk masalah utama yang sering terjadi pada ruang Handatsuke yaitu tentang teknik soldering. Teknik soldering yang keliru akan menimbulkan NG pada item berjenis Handa Tare dan Handa Oi. Rekomendasi untuk mengatasi masalah ini adalah dengan pemberian informasi ulang mengenai teknik dan metode soldering yang tepat sesuai dengan peta kerja tangan kanan \& kiri agar kawat timah tidak terlalu melebar pada saat dipanaskan dan ditempelkan ke permukaan item karena penggunaan tangan kanan \& kiri yang tidak seimbang. Selanjutnya untuk permasalahan pada proses pencucian item dengan larutan kimia, masalahnya yaitu pencucian tidak optimal dan dilakukan berulang kali karena tidak adanya batas minimum larutan pada bak pencucian.

3. Rekomendasi untuk mengatasi masalah ini yaitu dengan memberikan standart batas minimum larutan kimia pada bak pencucian dan merevisi standart penggantian larutan kimia rutin yang sudah jenuh 
4. sesuai dengan pengukuran tingkat kejenuhan konsentrasi larutan kimia yang digunakan.

\section{Saran}

Dari temuan permasalahan dan hasil penelitian disampaikan saran perbaikan sebagai berikut.

1. Perusahaan sebaiknya menambahkan metode FMEA untuk mendeteksi proses produksi dari machine, man dan methods selain 7 tools (ishikawa chart, control chart, dan aktivitas siklus PDCA) yang sudah digunakan perusahaan untuk meningkatkan produktivitas dan menurunkan produk cacat yang diproduksi. Karena dari hasil FMEA dapat diketahui lebih jelas mengenai penyebab dan efek yang ditimbulkan oleh kerusakan atau kesalahan yang telah terjadi pada man, machine, methods.

2. Perusahaan sebaiknya melakukan retraining ulang atau pemberian informasi mengenai jenis cacat yang terjadi pada flute foor, posisi, teknik \& metode kerja saat melakukan proses soldering. Hal ini akan berpeluang mengurangi potensi terjadinya item NG dan tentu akan mewujudkan tujuan perusahaan pada piramida kualitas yaitu zero complain.

3. Perusahaan sebaiknya melakukan cek rutin pada jig-jig yang digunakan pada ruang produksi Handatsuke melalui KK yang bertugas pada masing-masing shift kerja. Jika jig yang digunakan telah mengalami tingkat kerusakan lebih dari $30 \%$ maka akan dilakukan pendataan dan pemberian solusi terhadap jig tersebut apakah harus diperbaiki ataukah dengan penggantian total jig tersebut.

\section{DAFTAR PUSTAKA}

[1] Y. Monden, Toyota production system: an integrated approach to justin-time. CRc Press, 2011.

[2] M. H. Wang, "A cost-based FMEA decision tool for product quality design and management," Proc. 2011 IEEE Int. Conf. Intell. Secur. Informatics, pp. 297-302, 2011.

[3] A. P. Puvanasvaran, N. Jamibollah, N. Norazlin, and R. Adibah, "Poka-Yoke Integration into process FMEA," Aust. J. Basic Appl. Sci., vol. 8, no. 7, pp. 66-73, 2014.

[4] N. B. Puspitasari and A. Martanto, "Penggunaan FMEA dalam mengidentifikasi resiko kegagalan proses produksi sarung atm (alat tenun mesin)(studi kasus PT. Asaputex Jaya Tegal)," J@ ti Undip J. Tek. Ind., vol. 9, no. 2, pp. 93-98, 2014.

[5] D. A. Kifta and T. Munzir, "ANALISIS DEFECT RATE PENGELASAN DAN PENANGGULANGANNYA DENGAN METODE SIX SIGMA DAN FMEA DI PT. PROFAB INDONESIA," 2018.

[6] M. R. Suryoputro, A. D. Sari, and N. W. Widiatmaka, "Failure Mode and Effect Analysis (Fuzzy FMEA) Implementation for Forklift Risk Management in Manufacturing Company PT. XYZ," in IOP Conference Series: Materials Science and Engineering, 2019, vol. 528, no. 1, p. 12027.

[7] J. M. Juran and J. A. De Feo, Juran's quality handbook: the complete guide to performance excellence. McGraw-Hill Education, 2010.

[8] D. H. Stamatis, Failure mode and effect analysis: FMEA from theory to execution. Quality Press, 2003.

[9] M. A. Bennett, R. McDermott, and M. R. Beauregard, "The Basics of FMEA," 1996. 